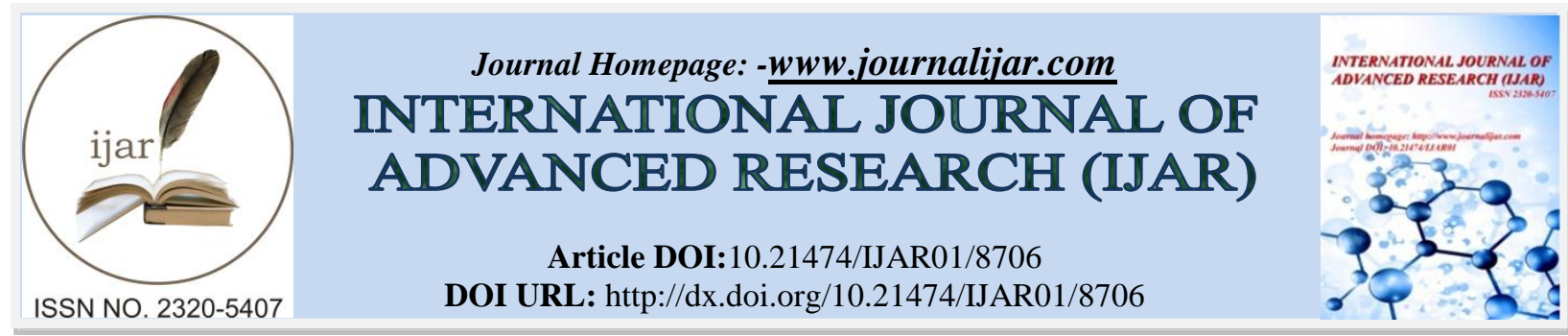

RESEARCH ARTICLE

\title{
Controlling the Pollution of Surabaya River Based on the Study of IPAL (Ijin Pembuangan Air Limbah) Conduct.
}

Yulfiah.

Environmental Engineering, Institute of Technology of Adhi Tama Surabaya (ITATS) Jl. Arief Rachman Hakim 100 Surabaya.

\section{Manuscript Info}

Manuscript History

Received: 16 January 2019

Final Accepted: 18 February 2019

Published: March 2019

Key words:-

river water quality, IPLC, pollution control.

\section{Abstract}

Surabaya River contributes great benefits to Surabaya people as its water still becomes the main source of Perusahaan Daerah Air Minum (PDAM) or Regional Water Utility Company. However, it has indications of water quality decrease due to over-pressure from irresponsible disposal of industrial waste. Therefore, a study is required to investigate: (a) the conduct of IPAL (Izin Pembuangan Air Limbah or Waste Water Disposal Permit) by industrial parties, (b) the identification of obstacles in implementing IPAL, and (c) the arrangement of activity plan in controlling and recovering the water quality of Surabaya River based on the results of review and identification. The result findings indicated that all parameters of waste water being tested at industries of target groups 01 and 02 did not exceed the quality standard of waste water. This kind of condition describes that all industries of target groups 01 and 02 have obeyed the conduct of IPLC. Meanwhile, there is only one industry at the target group 03 that meets the quality standard of waste water. All parameters of waste water at the three remaining industries have exceeded the threshold of waste water quality standard.

Copy Right, IJAR, 2019,. All rights reserved.

\section{Introduction:-}

All people agree that industrial activities have become one of the biggest incomes of a country. They hold vital roles for economic growth. Industry provides many job opportunities to society. However, industrial activities require raw materials from nature which are almost diminishing in number. They also have produced wastes degrading the quality of environment, including the quality of river water and its surrounding. For this reason, the management of industrial activity is necessary so as to make it in line with the law. By this way, the quality of environment can sustain and be assured. IPAL (Izin Pembuangan Air Limbah or Waste Water Disposal Permit) belongs to one of stipulations that must be obeyed by industrial doers.

IPAL becomes one of environemntal regulations that must be owned by every disposal activity of liquid waste into the water body. There are some requirements of IPAL that must be met by industries before they throw liquid waste into water body such as the availability of condusive IPAL (Izin Pengolahan Air Limbah or Waste Water Management Permit) and standardized waste water quality before being disposed to the water body.

Corresponding Author:- Yulfiah. 
One of rivers along Brantas River bank that has vital value to industrial community is Surabaya River. Its water supplies the need for standardized water to PDAMs (Perusahaan Daerah Air Minum or Regional Water Utility Company) in Gresik, Sidoarjo, and Surabaya. The water of Surabaya River becomes important component for production process of some industries operated around its river side. Unfortunately, Surabaya River has been a place for disposing liquid and solid wastes resulted from the activities of society and industries along its river side. There are more than 300 industries operated along Surabaya River. Wastes thrown by industries disobeying the stipulation of IPAL have caused severe water pollution in some parts of water body of Surabaya River, such as in Driyorejo and Warugunung Districs.

Some reviews were required as the initial steps for formulating a plan of activities in controlling pollution of Surabaya River. The reviews involved: (a) the implementation of IPAL by industries, (b) the identification of obstacles in conducting IPAL, and (c) the formulation of a plan for controlling pollution and recovering the water quality of Surabaya River based on the results of those reviews and identification.

\section{Review Of Related Literature}

Some articles related to the research theme have been learned to broaden insights. Research conducted by C.V. Privettea, S.W. Taylor, J.C. Hayes et al (2014) was aimed to get understanding on how development pattern at Greenville, SC and the surrounding metro area affected the water quality of Reedy River. Their main findings indicated that the effects of water quantity and quality was consistently higher at the growth scenario of area with more soil development. In this area, the surface flow increased but the water quality decreased.

Yan Lu, Hongwen Xu, Yuexiang Wang, and Yang Yang (2017) also carried out research on a river at Huai'an along Huaihe river bank area. All of them tried to calculate environmental capacity of river water from 2005 to 2014 by means of Analytic Hierarchy Process (AHP) method. The results of research indicated that social factors gave significant effects to environmental support of water and their changes were relatively consistent. Total populations and urbanization level became the main pressures to the environmental support of water in Huai'an City.

Other research was done by TA Ayandiran, OO Fawole, dan SO Dahunsi (2017) for building database of water quality in Oluwa River, South Western Nigeria, from April 2011 to March 2012. The research results demonstrated that all physical parameters did not exceed Nigeria Standard Industry (NIS) for drinking water yet. Moreover, all heavy metals passed the level permitted by NIS and WHO standard for drinking water. All chemical parameters studied during the dry season were very different from those in rainy season except BOD.

In 2017, Richa Bhardwaj, Anshu Gupta, and J.K. Garg published their research intended for investigating the heavy metal pollution in Yamuna River, Delhi. It was conducted in December 2013 - August 2015. The research result showed that the average concentration of all heavy metals was sequentially as follows: $\mathrm{Fe}>\mathrm{Cu}>\mathrm{Zn}>\mathrm{Ni}>\mathrm{Cr}>\mathrm{Pb}$ $>\mathrm{Cd}$. The disposal channels of Najafgarh and Shahdara were two potential sources responsible for heavy metal contamination in Yamuna River.

The next research was underwent in Shahr Chai River, Urmia Lake, Iran by Kamran Zeinalzadeha and Elnaz Rezaeib (2017). It was aimed at investigating the technical ability of Principal Component Analysis (PCA) in identifying environmental effects of various acivities. Parameters of water quality were measured monthly from six river flows which were highly influenced by disposal of recreation centre and agricultural activity. In conclusion, PCA technique applied in different landscapes brought to the decrease of water quality of river downstream.

The other crucial research was done by Laurent Ahiablame and Raghavan Srinivasan (2018) in Limpopo River, South Africa. It was about temporal and special distribution of river water components as the materials for planning and managing sustainable water sources. The research results revealed that the water surplus period occurred within one to two years, while the dry period happened for three to five years during the research period from 1984 to 2013. There was $20 \%$ of the basin (most of East area) having sufficient water, while the remaining about $80 \%$ was dry. This research became the basis of formulating activities for Surabaya River management.

The research results carried out by J. Thompson, C.E. Pelc, W.R. Brogan III, and T.E. Jordan was published in 2018. It was aimed at measuring the values of nutrition and sediment in the water flow before and after river restoration. The final results reported that river restoration improved the function of water flow and diminished phosphate 44.8\%; phosphor 45.8\%; ammonium 48.3\%; nitrate 25.7\%; nitrogen 49.7\%, and suspended sediment $73.8 \%$. 
Some discussions related to the main topic of this research are presented as the following. Some violations of environmental regulations have been done by industries. They indicate low awareness from industrial parties to participate in the pollution prevention efforts. The activity of pollution control becomes the burden of industrial operation cost. Most of industry doers apply End of Pipe Treatment System for their production processes. It means that they just focus on the waste products resulted from industrial production processes. This system only emphasizes on the conduct of managing waste resulted from the whole production processes. To reduce production cost, socialization and education on the implementation of green industry among industrial parties are required.

The resource of river water is necessary for numerous activities. Every acivity needs river water in different qualities. Water quality means the condition of quality which can be noticed from physical, biological, chemical, and radiological parameters with regard to life quality. Water quality is also defined as the characteristics of water resource quality for certain purposes.

River water pollutant can be classified based on three things: (1) the differences of pollutant resource locations such as spot source and non-spot source; (2) the history of river water formation; and (3) pollutant types such as organic, volatile, neutral, and acid pollutants.

The distribution of river water pollutants from the original spot will decrease along with the movement of pollutants which are getting farther from it. This process will continue until reaching undangerous or very low content due to self purification of river. Self purification will keep running as long as it has not exceeded the limit of river water ability for natural river purification yet. The process of purification depends on time, distance, pollutant type, and physical condition of river. Self purification is also determined by factors of flow quantity, time, movement to downstream, water temperature, and aeration. It involves the mechanisms of filtration, sorption, chemical process, decomposition, and dilution process (Hefni Effendi, 2003).

River water will be used based on its quality level compared to the standardized water quality. To protect the quality of river water, the quality of liquid waste which will be thrown into river must be regulated through the stipulation of standardized quality of liquid waste. Quality standard has general characters or can be applied for all types of water bodies. Unfortunately, it is difficult to find out natural phenomena with identical characteristics. Almost all natural phenomena are unique. Therefore, typical study for understanding the quality of Surabaya River water is required, with regard to the conduct of IPAL. As a result, a plan for controlling pollution can be formulated by adapting the characteristics of Surabaya River.

\section{Discussion:-}

This research is expected to give constribution in decreasing pressure to Surabaya River ecosystem so as to be better through safety attempts for Surabaya River recommended by the research results. The research variables were: (a) variables of river water quality and waste water quality, (b) variable of IPAL conduct, (c) variable of potential obstacles encoutered by industries in conducting IPAL, and (d) variable of factors needed for controlling pollution and recovering the water quality of Surabaya River.

The targets of this research were industries located in Driyorejo Warugunung area, Driyorejo District, Gresik Regency, and Waru Gunung Distrct, Surabaya City. These industries were chosen based on the analyses on the data of IPAL ownership, industrial waste quality monitoring, and environmenal cases. In the other words, the target industries were classified into group 01, 02, and 03. The first group refers to industries having IPAL with good environmental performance, while the second group belongs to industries having IPAL with bad environmental performance. The last group refers to industries without IPAL. Each of groups 01 and 02 consists of 6 companies, whereas group 03 includes 4 companies. The following tables present the results of waste water quality testing to 16 companies which have been compared to the standardized quality of waste water.

Table 1. The Waste Water Quality of Target Industry of Group 01

\begin{tabular}{|c|c|c|c|c|}
\hline \multicolumn{5}{|c|}{ Company Code L1.1 } \\
\hline No & Parameter & Unit & Quality Standard & Analysis Result \\
\hline 1 & BOD & $\mathrm{mg} / \mathrm{l}$ & 70.00 & 69.87 \\
\hline 2 & COD & $\mathrm{mg} / \mathrm{l}$ & 150.00 & 121.26 \\
\hline 3 & TSS & $\mathrm{mg} / \mathrm{l}$ & 70.00 & 28.00 \\
\hline
\end{tabular}




\begin{tabular}{|c|c|c|c|c|}
\hline 4 & $\mathrm{~Pb}$ & $\mathrm{mg} / \mathrm{l}$ & 0.10 & 0.00 \\
\hline 5 & $\mathrm{pH}$ & - & $6-9$ & 7.16 \\
\hline \multicolumn{5}{|c|}{ Company Code L1.2 } \\
\hline No & Parameter & Unit & Quality Standard & Analysis Result \\
\hline 1 & BOD & $\mathrm{mg} / \mathrm{l}$ & 70.00 & 30.55 \\
\hline 2 & COD & $\mathrm{mg} / \mathrm{l}$ & 150.00 & 52.00 \\
\hline 3 & TSS & $\mathrm{mg} / \mathrm{l}$ & 70.00 & 9.00 \\
\hline 4 & $\mathrm{~Pb}$ & $\mathrm{mg} / \mathrm{l}$ & 0.10 & 0.00 \\
\hline 5 & $\mathrm{pH}$ & - & $6-9$ & 7.80 \\
\hline \multicolumn{5}{|c|}{ Company Code L1.3 } \\
\hline No & Parameter & Unit & Quaity Standard & Analysis Result \\
\hline 1 & BOD & $\mathrm{mg} / \mathrm{l}$ & 70.00 & 68.44 \\
\hline 2 & COD & $\mathrm{mg} / \mathrm{l}$ & 150.00 & 118.00 \\
\hline 3 & TSS & $\mathrm{mg} / \mathrm{l}$ & 70.00 & 16.00 \\
\hline 4 & $\mathrm{~Pb}$ & $\mathrm{mg} / \mathrm{l}$ & 0.10 & 0.00 \\
\hline 5 & $\mathrm{pH}$ & - & $6-9$ & 7.71 \\
\hline \multicolumn{5}{|c|}{ Company Code L1.4 } \\
\hline No & Parameter & Unit & Quality Standard & Analysis Result \\
\hline 1 & BOD & $\mathrm{mg} / \mathrm{l}$ & 50.00 & 27.40 \\
\hline 2 & COD & $\mathrm{mg} / \mathrm{l}$ & 100.00 & 48.00 \\
\hline 3 & TSS & $\mathrm{mg} / \mathrm{l}$ & 200.00 & 22.00 \\
\hline 4 & $\mathrm{Zn}$ & $\mathrm{mg} / \mathrm{l}$ & 10.00 & 0.08 \\
\hline \multicolumn{5}{|c|}{ Company Code L1.5 } \\
\hline No & Parameter & Unit & Quality Standard & Analysis Result \\
\hline 1 & BOD & $\mathrm{mg} / \mathrm{l}$ & 60.00 & 58.00 \\
\hline 2 & COD & $\mathrm{mg} / \mathrm{l}$ & 100.00 & 98.00 \\
\hline 3 & TSS & $\mathrm{mg} / \mathrm{l}$ & 50.00 & 49.00 \\
\hline 4 & Fatty Oil & $\mathrm{mg} / \mathrm{l}$ & 5.00 & 0.16 \\
\hline 5 & Sulfide $\left(\mathrm{H}_{2} \mathrm{~S}\right)$ & $\mathrm{mg} / \mathrm{l}$ & 0.50 & 0.10 \\
\hline 6 & $\mathrm{pH}$ & - & $6-9$ & 7.72 \\
\hline \multicolumn{5}{|c|}{ Company Code L1.6 } \\
\hline No & Parameter & Unit & Quality Standard & Analysis Result \\
\hline 1 & COD & $\mathrm{mg} / \mathrm{l}$ & 100.00 & 41.00 \\
\hline 2 & TSS & $\mathrm{mg} / \mathrm{l}$ & 50.10 & 22.00 \\
\hline 3 & TDS & $\mathrm{mg} / \mathrm{l}$ & 1500.00 & 1350.00 \\
\hline 4 & $\mathrm{pH}$ & - & $6-9$ & 8.19 \\
\hline
\end{tabular}

Table 2. The Waste Water Quality of Target Industry of Group 02

Company Code L2.1

\begin{tabular}{|l|l|l|l|l|}
\hline No & Parameter & Unit & Quality Standard & Analysis Result \\
\hline 1 & BOD & $\mathrm{mg} / \mathrm{l}$ & 80.00 & 24.71 \\
\hline 2 & COD & $\mathrm{mg} / \mathrm{l}$ & 15.00 & 40.00 \\
\hline 3 & $\mathrm{TSS}$ & $\mathrm{mg} / \mathrm{l}$ & 60.00 & 15.00 \\
\hline 4 & $\mathrm{NH}_{3}-\mathrm{N}$ & $\mathrm{mg} / \mathrm{l}$ & 5.00 & 2.03 \\
\hline 5 & $\mathrm{pH}$ & - & $6-9$ & 7.46 \\
\hline Company Code L2.2 & \multicolumn{5}{|l|}{} \\
\hline No & Parameter & Unit & Quality Standard & Analysis Result \\
\hline 1 & BOD & $\mathrm{mg} / \mathrm{l}$ & 100.00 & 96.11 \\
\hline 2 & COD & $\mathrm{mg} / \mathrm{l}$ & 200.00 & 178.00 \\
\hline
\end{tabular}




\begin{tabular}{|c|c|c|c|c|}
\hline 3 & TSS & $\mathrm{mg} / \mathrm{l}$ & 100.00 & 98.00 \\
\hline 4 & Fatty Oil & $\mathrm{mg} / \mathrm{l}$ & 30.00 & 6.68 \\
\hline 5 & $\mathrm{pH}$ & - & $6-9$ & 7.72 \\
\hline \multicolumn{5}{|c|}{ Company Code L2.3 } \\
\hline No & Parameter & Unit & Quality Standard & Analysis Result \\
\hline 1 & BOD & $\mathrm{mg} / \mathrm{l}$ & 50.00 & 12.22 \\
\hline 2 & COD & $\mathrm{mg} / \mathrm{l}$ & 100.00 & 21.00 \\
\hline 3 & TSS & $\mathrm{mg} / \mathrm{l}$ & 30.00 & 6.00 \\
\hline 4 & Fatty Oil & $\mathrm{mg} / \mathrm{l}$ & 6.00 & 0.00 \\
\hline 5 & $\mathrm{pH}$ & - & $6-9$ & 7.98 \\
\hline \multicolumn{5}{|c|}{ Company Code L2.4 } \\
\hline No & Parameter & Unit & Quality Standard & Analysis Result \\
\hline 1 & COD & $\mathrm{mg} / \mathrm{l}$ & - & 22.00 \\
\hline 2 & BOD & $\mathrm{mg} / \mathrm{l}$ & - & 38.00 \\
\hline 3 & TSS & $\mathrm{mg} / \mathrm{l}$ & 100.00 & 11.00 \\
\hline 4 & $\mathrm{Cr}$ & $\mathrm{mg} / \mathrm{l}$ & 1.00 & 0.19 \\
\hline 5 & $\mathrm{Ni}$ & $\mathrm{mg} / \mathrm{l}$ & 0.50 & 0.08 \\
\hline 6 & $\mathrm{Zn}$ & $\mathrm{mg} / \mathrm{l}$ & 15.00 & 0.09 \\
\hline 7 & $\mathrm{Mn}$ & $\mathrm{mg} / \mathrm{l}$ & 5.00 & 0.11 \\
\hline 8 & $\mathrm{Cd}$ & $\mathrm{mg} / \mathrm{l}$ & 0.10 & 0.00 \\
\hline 9 & $\mathrm{~Pb}$ & $\mathrm{mg} / \mathrm{l}$ & 1.00 & 0.00 \\
\hline 10 & $\mathrm{pH}$ & - & $6-9$ & 7.5 \\
\hline \multicolumn{5}{|c|}{ Company Code L2.5 } \\
\hline No & Parameter & Unit & Quality Standard & Analysis Result \\
\hline 1 & BOD & $\mathrm{mg} / \mathrm{l}$ & 70.00 & 67.00 \\
\hline 2 & COD & $\mathrm{mg} / \mathrm{l}$ & 150.00 & 112.20 \\
\hline 3 & TSS & $\mathrm{mg} / \mathrm{l}$ & 70.00 & 38.00 \\
\hline 4 & $\mathrm{~Pb}$ & $\mathrm{mg} / \mathrm{l}$ & 0.10 & 0.00 \\
\hline 5 & $\mathrm{pH}$ & - & $6-9$ & 6.95 \\
\hline
\end{tabular}

Table 2. Continued

\begin{tabular}{|c|c|c|c|c|}
\hline \multicolumn{5}{|c|}{ Company Code L2.6 } \\
\hline No & Parameter & Unit & Quality Standard & Analysis Result \\
\hline 1 & BOD & $\mathrm{mg} / \mathrm{l}$ & 75.00 & 26.05 \\
\hline 2 & COD & $\mathrm{mg} / \mathrm{l}$ & 180.00 & 44.00 \\
\hline 3 & TSS & $\mathrm{mg} / \mathrm{l}$ & 60.00 & 7.00 \\
\hline 4 & Fatty Oil & $\mathrm{mg} / \mathrm{l}$ & 15.00 & 1.99 \\
\hline 5 & Phospate $\left(\mathrm{P}_{2} \mathrm{O}_{4}\right)$ & $\mathrm{mg} / \mathrm{l}$ & 10.00 & 1.13 \\
\hline 6 & Detergent (LAS) & $\mathrm{mg} / \mathrm{l}$ & 30.00 & 3.26 \\
\hline 7 & $\mathrm{pH}$ & - & $6-9$ & 7.51 \\
\hline
\end{tabular}

Table 3. The Waste Water Quality of Target Industry of Group 03

Company Code L3.1

\begin{tabular}{|l|l|l|l|l|}
\hline No & Parameter & Unit & Quality Standard & Analysis Result \\
\hline 1 & BOD & $\mathrm{mg} / \mathrm{l}$ & 150.00 & 290.00 \\
\hline 2 & COD & $\mathrm{mg} / \mathrm{l}$ & 300.00 & 496.00 \\
\hline 3 & TSS & $\mathrm{mg} / \mathrm{l}$ & 100.00 & 215.00 \\
\hline 4 & CN & $\mathrm{mg} / \mathrm{l}$ & 0.20 & 0.00 \\
\hline 5 & pH & - & $6-9$ & 7.5 \\
\hline
\end{tabular}




\begin{tabular}{|c|c|c|c|c|}
\hline \multicolumn{5}{|c|}{ Company Code L3.2 } \\
\hline No & Parameter & Unit & Quality Standard & Analysis Result \\
\hline 1 & BOD & $\mathrm{mg} / \mathrm{l}$ & - & 21.00 \\
\hline 2 & $\mathrm{COD}$ & $\mathrm{mg} / \mathrm{l}$ & - & 36.00 \\
\hline 3 & TSS & $\mathrm{mg} / \mathrm{l}$ & 20.00 & 219.00 \\
\hline 4 & $\mathrm{CN}$ & $\mathrm{mg} / \mathrm{l}$ & 0.20 & 0.00 \\
\hline 5 & $\mathrm{Cr}^{+6}$ & $\mathrm{mg} / \mathrm{l}$ & 0.10 & 1.16 \\
\hline 6 & Total $\mathrm{Cr}$ & $\mathrm{mg} / \mathrm{l}$ & 0.50 & 1.56 \\
\hline 7 & $\mathrm{Cu}$ & $\mathrm{mg} / \mathrm{l}$ & 0.60 & 0.37 \\
\hline 8 & $\mathrm{Zn}$ & $\mathrm{mg} / \mathrm{l}$ & 1.00 & 0.37 \\
\hline 9 & $\mathrm{Ni}$ & $\mathrm{mg} / \mathrm{l}$ & 1.00 & 1.13 \\
\hline 10 & $\mathrm{Cd}$ & $\mathrm{mg} / \mathrm{l}$ & 0.05 & 0.08 \\
\hline 11 & $\mathrm{~Pb}$ & $\mathrm{mg} / \mathrm{l}$ & 0.10 & 0.03 \\
\hline 12 & $\mathrm{pH}$ & - & $6-9$ & 7.63 \\
\hline \multicolumn{5}{|c|}{ Company Code L3.3 } \\
\hline No & Parameter & Unit & Quality Standard & Analysis Result \\
\hline 1 & BOD & $\mathrm{mg} / \mathrm{l}$ & 100.00 & 50.00 \\
\hline 2 & COD & $\mathrm{mg} / \mathrm{l}$ & 350.00 & 88.00 \\
\hline 3 & TSS & $\mathrm{mg} / \mathrm{l}$ & 250.00 & 13.00 \\
\hline 4 & Fatty Oil & $\mathrm{mg} / \mathrm{l}$ & 0.25 & 0.00 \\
\hline 5 & Total Ammonia $\left(\mathrm{NH}_{3}-\mathrm{N}\right)$ & $\mathrm{mg} / \mathrm{l}$ & 20.00 & 0.12 \\
\hline 6 & $\mathrm{pH}$ & - & $6-9$ & 7.9 \\
\hline
\end{tabular}

Table 3. Continued

Company Code L3.4

\begin{tabular}{|l|l|l|l|l|}
\hline No & Parameter & Unit & Quality Standard & Analysis Result \\
\hline 1 & BOD & $\mathrm{mg} / \mathrm{l}$ & 50.00 & 8750.00 \\
\hline 2 & COD & $\mathrm{mg} / \mathrm{l}$ & 150.00 & 14800.00 \\
\hline 3 & TSS & $\mathrm{mg} / \mathrm{l}$ & 50.00 & 224.00 \\
\hline 4 & Phenol & $\mathrm{mg} / \mathrm{l}$ & 1.00 & 0.69 \\
\hline 5 & Total Chrome & $\mathrm{mg} / \mathrm{l}$ & 1.00 & 1.24 \\
\hline 6 & Fatty Oil & $\mathrm{mg} / \mathrm{l}$ & 3.60 & 12.00 \\
\hline 7 & Total Ammonia $\left(\mathrm{NH}_{3}-\mathrm{N}\right)$ & $\mathrm{mg} / \mathrm{l}$ & 8.00 & 4.77 \\
\hline 8 & Sulfide $\left(\mathrm{H}_{3} \mathrm{~S}\right)$ & $\mathrm{mg} / \mathrm{l}$ & 0.30 & 0.26 \\
\hline 9 & pH & - & $6-9$ & 4.65 \\
\hline
\end{tabular}

The result of analysis demonstrated that all parameters being tested in target industry of Groups 01 and 02 did not exceed the quality standard of waste water. It indicated that both groups obeyed the conduct of IPAL. Meanwhile, the result of analysis in target industry of Group 03 reported that there were three companies disobeying the stipulation of IPAL. All parameters of waste water being tested exceeded the quality standard of waste water. There was only one industry fulfilling the quality standard of waste water quality.

The research findings obtained some obstacles encountered by industries for implementing IPAL as follows:

1. Institution giving business permit lacks of monitoring the permit that has been issued.

2. Business doers have low awareness in controlling their own industrial waste pollution (self-control).

3. People have low participation and care in monitoring industrial waste disposal. They much rely on the role of government for monitoring process.

4. Some business doers have perception that the cost of waste management and control will become the burden of production cost.

5. Some industries are not tranparent in providing information on the environmental management. 
Based on those data, a plan of activity for controlling pollution and recovering the water quality of Surabaya River are formulated. It assumes that all components of society have standardized environmental management activity. Therefore, information transparency is required in terms of environmental management activity, financial support allocation, society awareness socialization for the sake of active participation in environmental management. The key element of a program aimed for controlling pollution and recovering the water quality of Surabaya River is empowerment program through partnership, behavior and awareness nurture, as well as monitoring and controlling.

\section{Conclusion:-}

Target industry of groups 01 and 02 has obeyed the conduct of IPAL. All parameters of waste water did not exceed the quality standard. Meanwhile, the result of analysis on waste water in the target industry of group 03 showed that there were three industries disobeying the IPAL conduct as all parameters of waste water being tested exceeded the quality standard. Only one industry met the threshold of quality standard of waste water.

A plan of activity for controlling pollution and recovering the water quality of Surabaya River consists of two subsystems namely the system of partnership in environmental management as well as the system of pollution control and water quality recovery for Surabaya River. The implementation of both systems will involve society empowerment.

\section{References:-}

1. C.V. Privettea, S.W. Taylor, J.C. Hayes, L.S. Hallo, H.B. Nixe, 2014, Costs associated with mitigating the impacts on water quality of future development within the Reedy River watershed using various best management practices, Journal Ecological Engineering 71 (2014) 326-334.

2. Hefni Effendi, 2003, Telaah Kualitas Air Bagi Pengelolaan Sumberdaya dan Lingkungan, Kanisius, Yogyakarta.

3. J. Thompson, C.E. Pelc, W.R. Brogan III, T.E. Jordan, 2018, The multiscale effects of stream restoration on water quality, Journal Ecological Engineering 124 (2018) 7-18.

4. Kamran Zeinalzadeha, Elnaz Rezaeib, 2017, Determining spatial and temporal changes of surface water quality using principal component analysis, Journal of Hydrology: Regional Studies 13 (2017) 1-10.

5. Laurent Ahiablame, Raghavan Srinivasan, 2018, Spatial and temporal distribution of blue water in the Limpopo River Basin, Southern Africa: A case study Esther Mosase, Journal Ecohydrology \& Hydrobiology 222 (2018) $1-14$.

6. Richa Bhardwaj, Anshu Gupta, J.K. Garg, 2017, Evaluation of heavy metal contamination using environmetrics and indexing approach for River Yamuna, Delhi stretch, India, Journal Water Science, accepted 20 February 2017.

7. TA Ayandiran, OO Fawole, SO Dahunsi, 2017, Water Quality Assessment of Bitumen polluted Oluwa River, South-Western Nigeria, Journal Water Resources and Industry Accepted date: 7 December 2017.

8. Yan Lu, Hongwen Xu, Yuexiang Wang, Yang Yang, 2017, Evaluation of Water Environmental Carrying Capacity of City in Huaihe River Basin Based on the AHP Method: A Case in Huai'an City, Journal Water Resources and Industry Accepted date: 15 October 2017. 